\title{
Cardiovascular risk comorbidities in rheumatoid arthritis patients and the use of anti-rheumatic drugs: a cross-sectional real- life study
}

Gustavo Nogueira Schincariol Vicente ${ }^{1 *}$ D, Ivânio Alves Pereira1, Gláucio Ricardo Werner de Castro1, Licia Maria Henrique da Mota², Ana Paula Carnieletto ${ }^{1}$, Dhara Giovanna Santin de Souza',

Fabiana Oenning da Gama', Ana Beatriz Vargas Santos ${ }^{3}$, Cleandro Pires de Albuquerque ${ }^{2}$, Manoel Barros Bértolo ${ }^{4}$, Paulo Louzada Júnior ${ }^{5}$, Rina Dalva Neubarth Giorgi ${ }^{6}$, Sebastião Cezar Radominski,

Maria Fernanda Brandão Resende Guimarães ${ }^{8}$, Karina Rossi Bonfiglioli ${ }^{9}$,

Maria de Fátima Lobato da Cunha Sauma ${ }^{10}$, Claiton Viegas Brenol ${ }^{11}$ and Geraldo da Rocha Castelar Pinheiro ${ }^{3}$

\begin{abstract}
Background: Rheumatoid arthritis (RA) is a common autoimmune systemic inflammatory disease. In addition to joint involvement, RA patients frequently have other comorbidities, such as cardiovascular diseases. Drugs used for RA treatment may increase or decrease the risk of a cardiovascular event. This study aims to analyze cardiovascular risk comorbidities in patients with RA and the correlation with the use of anti-rheumatic drugs.

Methods: Cross-sectional study conducted based on the real-life rheumatoid arthritis study database - REAL, a prospective observational cohort study. Associations between the use of anti-rheumatic drugs and the presence of comorbidities were represented by their prevalence ratio and evaluated using the Chi-square or Fisher's Exact tests.

Results: We assessed 1116 patients, 89.4\% women, mean age of 55.15 years and predominance of seropositive disease. $63.3 \%$ had some cardiovascular comorbidity, predominantly hypertension (49.9\%). The use of glucocorticoids was observed in $47.4 \%$ of patients and there was a significant tendency of lower use of these drugs in the presence of dyslipidemia (PR: 0.790; $p=0.007$ ). We observed that the presence of cardiovascular comorbidities was associated with higher use of bDMARDs (PR:1.147; $p=0.003$ ).
\end{abstract}

Conclusions: The presence of cardiovascular risk comorbidities was confirmed to be higher in RA patients. Different treatment strategies using less glucocorticoids in the presence of dyslipidemia and more common use of bDMARDs in patients with cardiovascular comorbidities suggest that rheumatologists are aware of the potential influence of the DMARDs in the risk of cardiovascular event. Reinforcing these results, we highlight the need for a better baseline assessment to guide the choice of anti-rheumatic drugs in RA patients who have comorbidities.

Keywords: Rheumatoid arthritis, Cardiovascular diseases, Treatment

\footnotetext{
* Correspondence: gustavo_schincariol@hotmail.com

${ }^{1}$ Universidade do Sul de Santa Catarina- UNISUL, Florianópolis, SC, Brazil

Full list of author information is available at the end of the article
}

(c) The Author(s). 2021 Open Access This article is licensed under a Creative Commons Attribution 4.0 International License, which permits use, sharing, adaptation, distribution and reproduction in any medium or format, as long as you give appropriate credit to the original author(s) and the source, provide a link to the Creative Commons licence, and indicate if changes were made. The images or other third party material in this article are included in the article's Creative Commons licence, unless indicated otherwise in a credit line to the material. If material is not included in the article's Creative Commons licence and your intended use is not permitted by statutory regulation or exceeds the permitted use, you will need to obtain permission directly from the copyright holder. To view a copy of this licence, visit http://creativecommons.org/licenses/by/4.0/. 


\section{Background}

Rheumatoid arthritis (RA) is a chronic, systemic and immune-mediated inflammatory disease that affects joints, connective and fibrous tissue, muscles, and tendons with preferential involvement in the third to fifth decade of life $[1,2]$. Additionally, it causes lower life expectancy in 3 to 10 years and higher mortality rate in affected population compared to the general population $[1,3]$.

RA also involves the occurrence of extra-articular manifestations and comorbidities, with a higher prevalence of cardiovascular and pulmonary diseases, neoplasms, osteoporosis, changes in body composition and neuropsychiatric diseases [1, 4]. The most common and serious comorbidities are cardiovascular diseases (CVD) [5-7], being the main cause of increased premature mortality in this group $[1,8]$. This fact is attributed to: the higher prevalence of traditional cardiovascular risk factors in these individuals, such as systemic arterial hypertension (SAH), diabetes mellitus (DM), dyslipidemia and obesity; the side effects of drugs used for treatment; and, mainly, the systemic inflammatory activity of RA, which determines endothelial injury and accelerated atherogenesis [5, $6,8,9]$. Thus, it is possible to infer that the RA behaves as an independent risk factor for CVD [10].

The objective of RA treatment is its complete clinical remission, or, at least, to lower its activity [1, 11-13], thereby controlling systemic inflammation and reducing the risk of cardiovascular mortality [7, 14]. Drugs may positively or negatively influence cardiovascular risk comorbidities [15-18].

This study aims to analyze cardiovascular risk comorbidities in patients with RA and the correlation with the use of anti-rheumatic drugs.

\section{Methods}

The Rheumatoid Arthritis in Real Life (REAL) [19] is a prospective multi-center observational cohort study with 12 months of follow-up. The objectives were to describe the demographic, clinical, and therapeutic characteristics of Brazilian patients with RA and evaluate their treatment adherence, safety of pharmacological treatment and impact on the quality of life, physical function, and work ability.

Eleven tertiary care public health centers specialized in caring for RA patients were selected to represent the five geographic regions in Brazil. The recruitment period began on August 12, 2015 and ended on April 15, 2016. Patients were followed-up for approximately 12 months with systematic data collection at the initial visit (baseline), intermediate visit (6 months \pm 1 month), and final visit (12 months \pm 1 month) with an additional descriptive report of any other unscheduled visit. The present study is a cross-sectional evaluation of the data collected during the initial visit.
Patients included in the database were of both sexes, with RA according to the ACR 1987 [20] or ACR/ EULAR 2010 [21] classification criteria, over 18 years of age, and with records of at least 6 months of medical clinical monitoring before the study. Patients with associated diseases that compromised the evaluation of the variables used in the study were excluded, namely: major depression, malignant neoplasia, use of dialysis and equivalent.

A sample of 1116 patients was calculated as statistically significant to detect the Prevalence Ratio of the outcomes of interest (use of non-steroidal antiinflammatory drugs (NSAIDs), corticoids and disease modifying drugs (DMARDs) of at least double (PR: 2.0) when comparing patients with (exposed) and without (unexposed) comorbidities, with expected prevalence of $5 \%$ within significance level $(p<0.05)$ and statistical power of $80 \%$.

The dependent variables included the drugs used for RA treatment: NSAIDs, glucocorticoids, synthetic and biological DMARDs. The sDMARDs included were methotrexate, leflunomide, antimalarials-chloroquine/ hydroxychloroquine-, sulfasalazine and the JAK-kinase inhibitors (tofacitinib), a specific target synthetic DMAR D. All grouped biologicals were analyzed and subsequently separated into anti-TNFs (adalimumab, infliximab, etanercept, certolizumab, golimumab), anti-IL6r (tocilizumab), abatacept and rituximab. For glucocorticoids (prednisone), associations with use and dose were analyzed, with cut-off point at $10 \mathrm{mg}(<10 \mathrm{mg}$ and $\geq 10$ $\mathrm{mg})$.

The independent variables analyzed were sociodemographic profile, laboratory parameters and comorbidities of cardiovascular risk. Sociodemographic factors used were gender, age, and education. The clinical laboratory parameters studied were the duration of the disease, presence or absence of erosive disease, the autoantibodies Rheumatoid Factor (RF) and anti-citrullinated protein antibody (ACPA), and disease activity, the latter by means of the Disease Activity Score using 28 Joint Counts (DAS28). Cardiovascular comorbidities were initially grouped in a single variable and later discriminated in the traditional risk factors - SAH, DM and dyslipidemia - and in the specific cardiovascular events - cerebrovascular disease, peripheral vascular disease, acute myocardial infarction (AMI) and congestive heart failure (CHF). Finally, Charlson comorbidity index (CCI) and age-adjusted Charlson comorbidity index (ACCI) were analyzed.

The Kolmogorov-Smirnov test was used to assess the normality of the Charlson Comorbidity Index variable. Due to the non-normal distribution, the data were presented in median (interquartile range). 
The transversal data collected were tabulated on an electronic medium (Excel) and analyzed on SPSS 24.0 software (Statistical Package for the Social Sciences SPSS Version 24.0). Chicago: SPSS Inc.; 2016. The categorical variables were expressed as their absolute (n) and relative (\%) frequencies. The means and standard deviations were calculated for the quantitative variables. The measure of association, represented by the Prevalence Ratio (PR), was evaluated by means of Chi-square Test or Fisher's Exact Test, at 5\% significance level and 95\% confidence interval (CI).

The present study was approved by the research ethics committee of the University of Southern Santa Catarina, under CAAE 45781015.8.2005.5369.

\section{Results}

A cohort of 1116 patients, $89.4 \%$ female and mean age of 55.15 years, participated in the study. As for the other sociodemographic characteristics of the participants, a more detailed analysis has already been published [19], reproduced in Table 1. When evaluating clinical and laboratory data, we found that $39.5 \%$ of them were smokers or former smokers; the mean disease duration was 14.5 years. There were predominance of erosive (54.9\%) and seropositive diseases, with positive RF in $78.6 \%$ and anti-CCP in $76.8 \%$.

Table 2 describes the comorbidities of cardiovascular risk in the study population. We observed that $63.6 \%$ of the patients had at least one of these comorbidities, more frequently SAH (49.9\%), dyslipidemia (32.5\%) and DM (14.9\%).

Regarding the drugs used for RA treatment, we found that $47.4 \%$ of patients used glucocorticoids, of this percentage, $15.6 \%$ took doses higher than or equal to $10 \mathrm{mg}$. NSAIDs were used on demand by $66.6 \%$ of the participants. Methotrexate was the most used sDMARD (66.5\%), followed by leflunomide (33.9\%). Regarding bDMARDs, $35.7 \%$ of patients used some of them, most frequently anti-TNFs (19.9\%). Other drugs and their frequencies of use can be found in Table 3.

Table 4 shows the association between the use of glucocorticoids and cardiovascular comorbidities. There was a significant association (PR:0.790; $p=0.007$ ) between the presence of dyslipidemia and non-use of glucocorticoids.

We found no significant association between the use of NSAIDs and the presence of cardiovascular comorbidities.

The use of tofacitinib and sDMARDs (methotrexate, leflunomide, anti-malarial drugs and sulfasalazine) had no significant association with the presence of cardiovascular comorbidities. Table 5 shows the results obtained for methotrexate and leflunomide, the two main sDMARDs used by the population under study.
Table 1 Sociodemographic, clinical and laboratory characteristics of Rheumatoid Arthritis patients of the REAL study [19]

\begin{tabular}{ll}
\hline Variables & $\mathbf{n}(\%)$ \\
\hline Gender $(n=1116)$ & $998(89.4)$ \\
$\quad$ Female & $55.15(21-$ \\
Age - Mean (standard deviation) $(n=1116)$ & $88)$ \\
Education time (years) $(n=1076)$ & \\
$\quad 0-4$ years & $301(28)$ \\
$5-11$ years & $629(58.4)$ \\
$\quad \geq 12$ years & $146(13.6)$ \\
Disease duration (years) - mean (standard deviation) & $14.58(1-$ \\
$(n=1116)$ & $57)$ \\
Erosive disease $(n=1096)$ & \\
$\quad$ Yes & $602(54.9)$ \\
DAS 28 vSH Score ${ }^{\mathbf{a}}-$ mean (standard deviation) & $3.62(0-8)$ \\
Smoking $(n=1116)$ & \\
Smoker & $121(10.8)$ \\
Former Smoker & $320(28.7)$ \\
Never Smoked & $675(60.5)$ \\
Rheumatoid Factor $(n=1098)$ & \\
Positive & $863(78.6)$ \\
ACPA ${ }^{\mathbf{b}}(n=479)$ & \\
Positive & $368(768)$ \\
\hline
\end{tabular}

${ }^{\mathrm{a}}$ Disease Activity Score Index-28 Joints (DAS28); ${ }^{\mathrm{b}}$ Anti-citrullinated peptide antibody

Table 2 Cardiovascular comorbidities of rheumatoid arthritis patients of the REAL study [19]

\begin{tabular}{ll}
\hline Variables $(\boldsymbol{n}=\mathbf{1 1 1 6})$ & $\mathbf{n}(\%)$ \\
\hline Cardiovascular Comorbidities & 710 \\
Systemic Arterial Hypertension -SAH & $(63.6)$ \\
& 557 \\
Dyslipidemia & $(49.9)$ \\
Diabetes Mellitus & 363 \\
& $(32.5)$ \\
Congestive Heart Failure & 166 \\
Cerebrovascular Disease & $(14.9)$ \\
Acute Myocardial Infarction - AMI & $24(2.2)$ \\
Peripheral Vascular Disease & $24(2.2)$ \\
Charlson Comorbidity Index- CCI - median (interquartile & $0(1.0)$ \\
range) & $17(1.5)$ \\
\end{tabular}

Age-adjusted Charlson comorbidity index - CCI - median $2(2.0)$ (interquartile range) 
Table 3 Drugs used for rheumatoid arthritis treatment in the population of the REAL study [19]

\begin{tabular}{ll}
\hline Variables $(\boldsymbol{n}=\mathbf{1 1 1 6})$ & $\mathbf{n}(\%)$ \\
\hline Glucocorticoids & $529(47.4)$ \\
Dose $\geq 10 \mathrm{mg}(\boldsymbol{n}=527)$ & $82 / 527$ \\
Non-steroidal anti-inflammatory & $(15.6)$ \\
Methotrexate & $743(66.6)$ \\
Leflunomide & $742(66.5)$ \\
Antimalarials (chloroquine/hydroxychloroquine) & $378(33.9)$ \\
Sulfasalazine & $146(13.1)$ \\
Tofacitinib & $55(4.9)$ \\
Biologicals & $9(0.8)$ \\
$\quad$ Anti-TNF (adalimumab, infliximab, etanercept, & $398(35.7)$ \\
certolizumab, golimumab) & $222(19.9)$ \\
Anti-IL6r (tocilizumab) & \\
Abatacept & $55(4.9)$ \\
Rituximab & $72(6.5)$ \\
\hline
\end{tabular}

Table 6 shows the association between the presence of comorbidities and the use of bDMARDs. The use of these drugs was higher in patients with some cardiovascular comorbidity (PR:1.147; $p=0.003$ ) when compared to those without comorbidities. We found a similar association for SAH (PR:1.169; $p=0.011$ ) and AMI (PR: 4.330; $p=0.002)$. The presence of dyslipidemia also followed an equivalent pattern (PR:1.186; $p=0.052$ ). The main bDMARDs used by the population were anti-TNFs (19.9\%), but no significant association was found between their use and the presence of comorbidities.

Regarding tocilizumab, no significant association was found between its use and the presence of cardiovascular comorbidities.

We observed that patients with cardiovascular comorbidities showed a significantly higher use of abatacept comparing to those without comorbidities (PR:1.194; $p=0.038)$. The use of rituximab was more frequent in patients with SAH (PR:1.327; $p=0.028)$, DM (PR:2.006; $p=0.006)$ and AMI (PR:9.073; $p<0.001)$ than in patients without these diseases.

\section{Discussion}

The present study analyzed whether the presence of cardiovascular comorbidities was associated with the use of different anti-rheumatic drugs in this large Brazilian cohort of RA patients.

RA patients show a higher prevalence of cardiovascular risk comorbidities compared to the general population [6, 16], which was confirmed in our study [22] by high rates of SAH (49.9\%) and DM (14.9\%), higher than those described in other cohorts [6, 23-25]. There was found in this cohort a higher prevalence of $\mathrm{SAH}$ when comparing to the prevalence of this commorbity in the Brazilian population, this fact may be explained by the fact that RA patients experience a higher cardiovascular risk explained by the systemic inflammation experienced by these patients, that contributes for a higher prevalence of cardiovascular commorbities. However, we found lower rates of dyslipidemia than those reported by other authors [7, 26]. There was a high prevalence of AMI, peripheral vascular disease, cerebrovascular disease and CHF, the most common causes of premature death in RA patients $[1,9]$.

Excessive cardiovascular risk in this population is multifactorial $[8,9]$. It can be partially explained by the higher prevalence of traditional cardiovascular risk factors, such as SAH, type $2 \mathrm{DM}$, dyslipidemia, sedentary lifestyle and obesity $[5,6,16]$, which was confirmed in our study [22]. However, the main factor associated with this increased risk is systemic inflammation due to RA $[1,8,9]$. A recent study demonstrated that these combined elements explain $69.6 \%$ of the increase in cardiovascular risk [27].

Pro-inflammatory state caused by RA [1, 9, 10], with elevated C-reactive protein (CRP) and pro-inflammatory cytokines, such as tumor necrosis factor-alpha (TNF-a), IL-6 and IL-1, are associated with accelerated atherosclerosis, changes in lipid patterns (quantitative and qualitative), insulin resistance and endothelial dysfunction $[9,10]$. Other factors of the disease, such as presence of autoantibodies, extra-joint manifestations, disease activity and X-ray erosions, contribute to increasing cardiovascular risk [1, 10, 28, 29]. Therefore, we conclude that RA itself can be considered an independent risk factor for the development of CVD $[9,10]$.

A factor that can be associated with cardiovascular risk in RA patients is the drugs used for the management of the disease, which can influence cardiovascular risk positively or negatively $[10,15,17]$. Current recommendations state that the most important aspect in reducing the risk of cardiovascular events in RA patients is the reduction of disease activity using DMARDs, whether synthetic or biological, thus reducing chronic inflammation and its deleterious effects $[11-13,18,30]$. They are also proven to reduce atherosclerosis progression and, consequently, cardiovascular risk [18, 30, 31].

In addition, the use of different DMARDs should be individualized and take into account the presence of comorbidities that can be positively or negatively affected by these drugs $[11,18]$. Indeed, there are specific agreements that guide the choice of drugs for RA treatment based on the presence of these comorbidities [13, 15].

The use of glucocorticoids is related to a large spectrum of adverse events, such as uncontrolled SAH, dyslipidemia and especially DM [24], and their use is associated with a $47 \%$ increase in relative risk of all 
Table 4 Association of cardiovascular comorbidities with the use of glucocorticoids

\begin{tabular}{|c|c|c|c|c|c|}
\hline & & \multicolumn{2}{|c|}{ Glucocorticoids } & \multirow[b]{2}{*}{ PR^ (IC95\%) } & \multirow[b]{2}{*}{$p \neq$} \\
\hline & & Yes $n *(\%)$ & No $n^{*}(\%)$ & & \\
\hline \multirow[t]{2}{*}{ Cardiovascular Comorbidities } & Yes & $322(66.9)$ & $388(66.1)$ & $0.921(0.842-1.007)$ & 0.070 \\
\hline & No & $207(39.1)$ & $199(33.9)$ & $1.154(0.988-1.348)$ & \\
\hline \multirow[t]{2}{*}{ Systemic Arterial Hypertension } & Yes & $257(48.6)$ & $300(51.1)$ & $0.951(0.845-1.070)$ & 0.400 \\
\hline & No & $272(51.4)$ & $287(48.9)$ & $1.052(0.935-1.182)$ & \\
\hline \multirow[t]{2}{*}{ Dyslipidemia } & Yes & $151(28.5)$ & $212(36.1)$ & $0.790(0.665-0.939)$ & 0.007 \\
\hline & No & $378(71.5)$ & $375(63.9)$ & $1.119(1.031-1.213)$ & \\
\hline \multirow[t]{2}{*}{ Diabetes Mellitus } & Yes & $74(14)$ & $92(15.7)$ & $0.893(0.673-1.184)$ & 0.430 \\
\hline & No & $455(86)$ & $495(84.3)$ & $1.020(0.971-1.071)$ & \\
\hline \multirow[t]{2}{*}{ Congestive Heart Failure } & Yes & $11(2.1)$ & $13(2.2)$ & $0.939(0.424-2.078)$ & 0.876 \\
\hline & No & $518(97.9)$ & $574(97.8)$ & $1.001(0.984-1.019)$ & \\
\hline \multirow[t]{2}{*}{ Cerebrovascular Disease } & Yes & $12(2.3)$ & $12(2)$ & $1.110(0.503-2.449)$ & 0.797 \\
\hline & No & $517(97.7)$ & $575(98)$ & $0.998(0.980-1.015)$ & \\
\hline \multirow[t]{2}{*}{ Acute Myocardial Infarction } & Yes & $8(1.5)$ & $9(1.5)$ & $0.986(0.383-2.538)$ & 0.977 \\
\hline & No & $521(98.5)$ & $578(98.5)$ & $1.000(0.986-1.015)$ & \\
\hline \multirow[t]{2}{*}{ Peripheral Vascular Disease } & Yes & $4(0.8)$ & $4(0.7)$ & $1.110(0.279-4.415)$ & 1.000 \\
\hline & No & $525(99.2)$ & $583(99.3)$ & $0.999(0.989-1.009)$ & \\
\hline
\end{tabular}

*Absolute frequencies; ^ Prevalence Ratio ₹ Significance level

cardiovascular events and general mortality in RA patients, and this increase in risk is dependent on dose and time of use $[17,24,32]$. In the study population, the use of corticoids $(47.2 \%)$ was lower than that reported by another Latin American study [33], but similar to that found in the cohort of Wilson et al [24].
Like corticosteroids, all NSAIDs [34], selective COX-2 in particular, are associated with a $20 \%$ increase in the relative risk of all cardiovascular events and lead to uncontrolled SAH [17, 35]. Therefore, it is recommended that NSAIDs be used as symptomatic medication for as little time as possible, and their use should be avoided in

Table 5 Association between cardiovascular comorbidities and the use of Methotrexate and Leflunomide

\begin{tabular}{|c|c|c|c|c|c|c|c|}
\hline & & \multicolumn{3}{|c|}{ Methotrexate } & \multicolumn{3}{|c|}{ Leflunomide } \\
\hline & & Yes $n^{*}(\%)$ & PR^ (IC95\%) & $p \neq$ & Yes $n^{*}(\%)$ & PR^ (IC95\%) & $p \neq$ \\
\hline \multirow[t]{2}{*}{ Cardiovascular Comorbidities } & Yes & $463(62.4)$ & $0.945(0.862-1.036)$ & 0.232 & $251(66.4)$ & $1.068(0.975-1.170)$ & 0.167 \\
\hline & No & 279 (37.6) & 1.107 (0.935-1.311) & & 127 (33.6) & $0.889(0.750-1.053)$ & \\
\hline \multirow[t]{2}{*}{ Systemic Arterial Hypertension } & Yes & $365(49.2)$ & $0.958(0.847-1.083)$ & 0.499 & $195(51.6)$ & $1.052(0.931-1.188)$ & 0.423 \\
\hline & No & $377(50.8)$ & $1.044(0.921-1.184)$ & & $183(48.4)$ & $0.950(0.838-1.078)$ & \\
\hline \multirow[t]{2}{*}{ Dyslipidemia } & Yes & $236(31.8)$ & $0.937(0.785-1.117)$ & 0.469 & $129(34.1)$ & $1.076(0.903-1.283)$ & 0.414 \\
\hline & No & $506(68.2)$ & $1.033(0.946-1.127)$ & & $249(65.9)$ & $0.965(0.884-1.053)$ & \\
\hline \multirow[t]{2}{*}{ Diabetes Mellitus } & Yes & $111(15)$ & $1.017(0.755-1.371)$ & 0.910 & $52(13.8)$ & $0.891(0.657-1.207)$ & 0.453 \\
\hline & No & $631(85)$ & $0.997(0.947-1.050)$ & & $326(86.2)$ & $1.020(0.970-1.073)$ & \\
\hline \multirow[t]{2}{*}{ Congestive Heart Failure } & Yes & $18(2.4)$ & $1.512(0.605-3.777)$ & 0.372 & $7(1.9)$ & $0.804(0.336-1.922)$ & 0.623 \\
\hline & No & $724(97.6)$ & $0.992(0.975-1.009)$ & & $371(98.1)$ & $1.005(0.987-1.023)$ & \\
\hline \multirow[t]{2}{*}{ Cerebrovascular Disease } & Yes & $14(1.9)$ & $0.706(0.316-1.574)$ & 0.392 & $9(2.4)$ & $1.171(0.517-2.652)$ & 0.704 \\
\hline & No & $728(98.1)$ & $1.008(0.989-1.028)$ & & $369(97.6)$ & $0.996(0.978-1.015)$ & \\
\hline \multirow[t]{2}{*}{ Acute Myocardial Infarction } & Yes & $12(1.6)$ & $1.210(0.429-3.408)$ & 0.718 & $3(0.8)$ & $0.418(0.121-1.447)$ & 0.200 \\
\hline & No & $730(98.4)$ & $0.997(0.982-1.012)$ & & $375(99.2)$ & $1.011(0.998-1.025)$ & \\
\hline \multirow[t]{2}{*}{ Peripheral Vascular Disease } & Yes & $5(0.7)$ & $0.840(0.202-3.496)$ & 1.000 & $5(1.3)$ & $3.254(0.782-13.543)$ & 0.129 \\
\hline & No & 737 (99.3) & $1.001(0.990-1.012)$ & & $373(98.7)$ & 0.991 (0.970-1.003) & \\
\hline
\end{tabular}

*Absolute frequencies; ^ Prevalence Ratio ₹ Significance level 
Table 6 Association between cardiovascular comorbidities and use of biologicals, in particular those of the anti-TNF class

\begin{tabular}{|c|c|c|c|c|c|c|c|}
\hline & & \multicolumn{3}{|l|}{ Biologicals } & \multicolumn{3}{|l|}{ Anti-TNF } \\
\hline & & Yes $n^{*}(\%)$ & $\mathrm{PR}^{\wedge}$ (IC95\%) & $p \neq$ & Yes $n *(\%)$ & $\mathrm{PR}^{\wedge}(\mathrm{IC} 95 \%)$ & $p \neq$ \\
\hline \multirow[t]{2}{*}{ Cardiovascular Comorbidities } & Yes & $276(69.3)$ & $1.147(1.050-1.253)$ & 0.003 & $148(66.7)$ & $1.060(0.954-1.179)$ & 0.292 \\
\hline & No & $122(30.7)$ & $0.775(0.652-0.922)$ & & $74(33.3)$ & $0.898(0.731-1.101)$ & \\
\hline \multirow[t]{2}{*}{ Systemic Arterial Hypertension } & Yes & $219(55)$ & $1.169(1.039-1.315)$ & 0.011 & $116(52.3)$ & $1.059(0.919-1.221)$ & 0.436 \\
\hline & No & $179(45)$ & $0.850(0.747-0.967)$ & & $106(47.7)$ & $0.942(0.808-1.097)$ & \\
\hline \multirow[t]{2}{*}{ Dyslipidemia } & Yes & $144(36.2)$ & $1.186(1.000-1.407)$ & 0.052 & $80(36)$ & $1.138(0.932-1.390)$ & 0.212 \\
\hline & No & $254(63.8)$ & $0.918(0.841-1.003)$ & & $142(64)$ & $0.936(0.840-1.043)$ & \\
\hline \multirow[t]{2}{*}{ Diabetes Mellitus } & Yes & $65(16.3)$ & $1.161(0.872-1.546)$ & 0.308 & $31(14)$ & $0.925(0.644-1.328)$ & 0.670 \\
\hline & No & $333(83.7)$ & $0.974(0.924-1.020)$ & & $191(86)$ & $1.013(0.955-1.076)$ & \\
\hline \multirow[t]{2}{*}{ Congestive Heart Failure } & Yes & $10(2.5)$ & $1.289(0.578-2.874)$ & 0.535 & $3(1.4)$ & $0.575(0.173-1.911)$ & 0.448 \\
\hline & No & $388(97.5)$ & $0.994(0.976-1.013)$ & & $219(98.6)$ & $1.010(0.992-1.029)$ & \\
\hline \multirow[t]{2}{*}{ Cerebrovascular Disease } & Yes & $4(1)$ & $0.361(0.124-1.048)$ & 0.054 & $1(0.5)$ & $0.175(0.024-1.289)$ & 0.066 \\
\hline & No & $394(99)$ & $1.018(1.002-1.035)$ & & $222(99.5)$ & $1.022(1.008-1.036)$ & \\
\hline \multirow[t]{2}{*}{ Acute Myocardial Infarction } & Yes & $12(3)$ & $4.330(1.536-12.201)$ & 0.002 & $3(1.4)$ & $0.863(0.250-2.977)$ & 1.000 \\
\hline & No & $386(97)$ & 0.977 (0.959-0.995) & & $219(98.6)$ & $1.002(0.985-1.020)$ & \\
\hline \multirow[t]{2}{*}{ Peripheral Vascular Disease } & Yes & $3(0.8)$ & $1.082(0.260-4.505)$ & 1.000 & $1(0.5)$ & $0.575(0.071-4.652)$ & 1.000 \\
\hline & No & $395(99.2)$ & $0.999(0.989-1.010)$ & & $221(99.5)$ & $1.003(0.993-1.014)$ & \\
\hline
\end{tabular}

*Absolute frequencies; ^ Prevalence Ratio ₹ Significance level

those with some previous cardiovascular event (AMI, CCI) or with high risk based on traditional risk factors $[11,12,15,36]$. In the present study, the use of NSAIDs was lower when compared to another cohort [7].

Since systemic inflammation caused by RA is the main determinant of increased cardiovascular risk, algorithms of RA treatment recommend the use of sDMARDs as the first line of treatment, methotrexate being the drug of choice [11-13, 18]. This finding was reproduced in our study, given that this was the most used DMARD by the population (66.5\%). As it is the most used drug, evidence of cardiovascular risk is more robust for methotrexate. Recent meta-analysis in RA patients has shown that the risk of all cardiovascular events is reduced by $28 \%$ with the use of methotrexate, with a special reduction in risk and recurrence of AMI [17]. In our study, the presence of some comorbidity or cardiovascular event was not associated with the higher or lower use of this drug, which can be explained by the fact that, being the drug of choice, its use should be preferable in all patients, regardless of the presence of comorbidities or previous events.

In our population, frequent use of leflunomide was evidenced to the detriment of other sDMARDs in RA treatment. The available data regarding this drug are scarce. It is known that leflunomide is associated with the occurrence and bad control of SAH $[13,18]$. Therefore, although it is not contraindicated, it should be avoided in hypertensive patients [13, 15, 18, 37]. In our population, we observed that this recommendation was not adopted, since the presence of hypertension was not associated with a lower use of this drug.

Biologicals are associated with reduced cardiovascular risk compared to patients who do not use them or those using sDMARDs $[17,25,30]$. Lee et al and Radner et al verified in their populations that the use of biological agents is less frequent in patients with comorbidities, especially cardiovascular ones $[25,38]$, which, according to recent protocols and recommendations, should in fact happen in the opposite way because of the cardiovascular benefit of these drugs $[11-13,18]$. In the present study, we found that bDMARDs tended to be more frequently used $(p=0.003)$ in patients with some comorbidity or cardiovascular event, whereas individually this tendency was similar only for SAH $(p=0.011)$ and AMI $(p=0.002)$. This is an important finding, considering that the use of bDMARDs is associated to lower chance of future cardiocascular event. Besides that, bDMARDs use allows more easily the reduction or suspension of corticosteroids, which is well stabished associated with a pro-inflamatory state. However, this finding could be related to a selection bias, in which more severe patients and those with more inflammatory activity tend to receive bDMARDs.

The risk of all cardiovascular events, especially AMI (RR 0.85), is reduced with the use of anti-TNF drugs, more than that observed with the use of sDMARDs, specially in patients who respond well to the medication $[17,18,30,39]$. Such protective effect was not identified for heart failure [17]. We found that the presence of 
comorbidities and cardiovascular events was not associated with use of anti-TNFs, contrasting with the guidelines $[11-13,18]$. This absence of association is particularly important when evaluating heart failure, given the recommendations to avoid the use of anti TNFs in patients with CHF, especially in more advanced stages $[14,18,30]$.

Abatacept and rituximab were the least frequently used drugs in our sample. The literature states that the risk reduction of cardiovascular events, such as AMI and stroke, with the use of abatacept is modestly higher comparing to anti-TNFs $[40,41]$, especially in patients with DM. For rituximab, data on cardiovascular outcomes are scarce, but their benefits seem to be comparable to those obtained with the use of anti-TNF [42]. In our study we observed that abatacept and rituximab tended to be used in patients with some cardiovascular risk factor like SAH, DM and AMI.

One limitations of this work is the impossibility to determine a causal relationship between the variables analyzed. Special care should also be taken in extrapolating these findings to the general population. Moreover, for some of the medications and comorbidities, the number of patients analyzed was small, which may have affected some of the associations found. One other limitation that should be mentioned is that the cardiovascular risk in these patients were not established by known formulas, which can influence at the analyses. In spite of the above, we underline that this work was a first attempt at evaluating the association between the presence of cardiovascular risk comorbidities and the use of antirheumatic drugs in the first large Brazilian RA cohort and may serve as a basis for further studies.

\section{Conclusion}

The findings of this study confirmed that the presence of comorbidities of cardiovascular risk is high in the RA population. Additionally, we observed that, for the patients of the REAL study, some of the recommendations by different algorithms, which advise taking into account the presence of cardiovascular comorbidities in the choice of some anti-rheumatic drugs, were adopted but could have been better implemented.

Given that RA is an independent risk factor for cardiovascular events itself, we highlight the need to better assess the cardiovascular risk of patients in order to guide the choice of different DMARDs, aiming at better cardiovascular outcomes.

\footnotetext{
Abbreviations

RA: Rheumatoid arthritis (RA); CVD: Cardiovascular diseases; SAH: Systemic arterial hypertension; DM: Diabetes mellitus; NSAIDs: Non-steroidal antiinflammatory drugs; DMARDs: Disease-modifying antirheumatic drugs; sDMARDs: Synthetic disease-modifying antirheumatic drugs; JAKquinase: Tirosina quinase; bDMARDs: Biological disease-modifying antirheumatic drugs; anti-TNF : Tumor necrosis factor inhibitor; anti-IL6r: Interleukin 6
}

nhibitor; BSR: Brazilian Society of Rheumatology; ACR: American College of Radiology; EULAR: European League Against Rheumatism; PR: Prevalence Ratio; P: Significance level; RF: Rheumatoid Factor; ACPA: Anti-citrullinated protein antibody; DAS 28 SCORE: Disease Activity Score Index 28 Joints; AMI: Acute myocardial infarction; CHF: Congestive heart failure; CCI: Charlson comorbidity index; ACCl: Age-adjusted Charlson comorbidity index; SPSS: Statistical Package for the Social Sciences; Cl: Confidence interval; CRP: C-reactive protein; TNFa: Tumor necrosis factor-alpha; IL1: Interleukin 1; IL6: Interleukin 6; COX-2: Cyclooxygenase-2; RR: Relative risk; LDL: Low density lipoprotein; TC: Total cholesterol; TG: Triglycerides; HDL: High density lipoprotein

\section{Acknowledgments}

We thank the Brazilian Society of Rheumatology and the team of the University of Southern Santa Catarina for the statistical analysis of the data.

\section{Authors' contributions}

GNSV: medical student responsible for the study, participated in all planning, execution and preparation of the manuscript. IAP: advisor and supervisor, responsible for outlining the study, participated in the analysis, data interpretation and critical review of the content. APC, DGSS: participated in the process of execution and content review. FOG: participated in the content execution and review process. GRCP, ABVS, CPA, MBB, PLJR, DNG, SCR, MFBRG, JRB, MFLCS, CVB, LMHM, GRWC: responsible for the 'Rheumatoid Arthritis in Real Life' database. The author(s) read and approved the final manuscript

\section{Funding}

This work was supported by the Brazilian Society of Rheumatology (BSR). For this project, BSR received specific grant support from the following companies: Bristol-Myers Squibb Farmacêutica Ltda; Eli Lilly do Brasil Ltda; Janssen-Cilag Farmacêuticos Ltda; Laboratórios Pfizer Ltda; Produtos Roche Químicos e Farmacêuticos S.A. and UCB Biopharma Ltda. The funding body or the companies had no role in the design of the study and collection, analysis, and interpretation of data and in writing the manuscript.

\section{Availability of data and materials}

All data generated or analyzed during this study are included in this article and its supplementary information files.

The data sets generated and analyzed during the current study are not public available, due to the institutions' ethical policy, and for this reason they are under the care of the authors but may be made available upon express request and provided that it is done within a reasonable time.

\section{Declarations}

\section{Ethics approval and consent to participate}

This study was approved by the National Commission of Ethics in Research (CONEP - Comissão Nacional de Ética em Pesquisa) - Ministry of Health. The coordinating center was the University of the State of Rio de Janeiro, and the approval number was 45781015.8.1001.5259. Each of the centers also obtained approval from the respective Institutional Review Boards. All patients signed the informed consent form.

\section{Consent for publication}

Not applicable.

\section{Competing interests}

GNSV: No financial disclosures; APC: No financial disclosures: DGSS: No financial disclosures; FOG: No financial disclosures; IAP: Has received consulting fees, speaking fees and supporting for internationals congresses from Roche, Pfizer, UCB Pharma, Eli-Lilly, Abbvie and Janssen; GRWC: No financial disclosures; GRCP: Has received consulting fees from AbbVie, BristolMyers Squibb, Eli Lilly, Glaxosmithkline, Janssen, Pfizer, Sanofi Genzyme and Roche; ABVS: Has received supporting for international medical events from AbbVie and Janssen; CPA: Has received personal fees and/or non-financial support from Pfizer, AbbVie, AstraZeneca, Janssen, Bristol-Myers Squibb, Roche, Novartis and UCB, outside the submitted work; MBB: Has participated in clinical and/or experimental studies related to this work and sponsored by Roche; has delivered speeches at events related to this work and sponsored by AbbVie and Pfizer; PLJ: Has received supporting for internationals 
congresses from Bristol-Myers Squibb, UCB and consulting fees from Pfizer; RDNG: Has received consulting fees, speaking fees and supporting for internationals congresses from Roche, Pfizer, Bristol-Myers Squibb, UCB, Eli-Lilly, AbbVie, Abbott and EMS; SCR: Has received consulting and speaking fees from Abbvie, Janssen, Pfizer, Roche and UCB; MFBRG: Has received speaking fees and supporting for congresses from AbbVie, Bristol-Myers Squibb, Janssen, Novartis, Pfizer, Roche and UCB; KRB: Has received speaking fees and supporting for international congresses from Roche, Pfizer, Bristol-Myers Squibb, Abbvie and Janssen; MFLCS: No financial disclosures; CVB: Has participated in clinical and/or experimental studies re- lated to this work and sponsored by AbbVie, BMS, Janssen, Pfizer and Roche; has received personal or institutional support from AbbVie, BMS, Janssen, Pfizer and Roche; has delivered speeches at events related to this work and sponsored by AbbVie, Janssen, Pfizer and Roche; CVB: Has participated in clinical and/or experimental studies related to this work and sponsored by AbbVie, BMS, Janssen, Pfizer and Roche; has received personal or institutional support from AbbVie, BMS, Janssen, Pfizer and Roche; has delivered speeches at events related to this work and sponsored by AbbVie, Janssen, Pfizer and Roche Ricardo Machado Xavier: Consultancies for Abbvie, BMS, GSK, Janssen, Lilly, Novartis, Pfizer, Roche, UCB. Clinical trials: Abbvie, UCB, Pfizer, GSK, Lilly; ESFC: No financial disclosures; LMHM: Has received personal or institutional support from AbbVie, Janssen, Pfizer and Roche; has delivered speeches at events related to this work and sponsored by AbbVie, Janssen, Pfizer, Roche and UCB.

\section{Author details}

'Universidade do Sul de Santa Catarina- UNISUL, Florianópolis, SC, Brazil. ${ }^{2}$ Hospital Universitário de Brasília, Universidade de Brasília, Brasília, DF, Brazil. ${ }^{3}$ Universidade do Estado do Rio de Janeiro, Rio de Janeiro, RJ, Brazil. ${ }^{4}$ Faculdade de Ciências Médicas, Universidade Estadual de Campinas, Campinas, SP, Brazil. ${ }^{5}$ Universidade de São Paulo, Ribeirão Preto, SP, Brazil. ${ }^{6}$ Instituto de Assistência Médica ao Servidor Público Estadual, Hospital do Servidor Público Estadual de São Paulo, São Paulo, SP, Brazil. " Universidade Federal do Paraná, Curitiba, PR, Brazil. ${ }^{8}$ Hospital das Clínicas, Universidade Federal de Minas Gerais, Belo Horizonte, MG, Brazil. ${ }^{9}$ Faculdade de Medicina, Universidade de São Paulo, São Paulo, SP, Brazil. ${ }^{10}$ Faculdade de Medicina, Universidade Federal do Pará, Belém, PA, Brazil. "'Universidade Federal do Rio Grande do Sul, Porto Alegre, RS, Brazil.

\section{Received: 19 February 2021 Accepted: 17 May 2021 Published online: 25 June 2021}

\section{References}

1. Smolen JS, Aletaha D, Barton A, Burmester GR, Emery P, Firestein GS, et al. Rheumatoid arthritis. Nat Rev Dis Prim [Internet]. 2018:4:1800 [acesso em 2020 ago 14]. Disponível em: https://doi.org/10.1038/nrdp.2018.1.

2. World Health Organization (WHO). Chronic rheumatic conditions. 2019 [acesso em 2020 ago 18]; Disponível em: https://www.who.int/chp/topics/ rheumatic/en/.

3. Myasoedova E, Davis JM, Crowson CS, Gabriel SE. Epidemiology of rheumatoid arthritis: rheumatoid arthritis and mortality. Curr Rheumatol Rep. 2010;12(5):379-85. https://doi.org/10.1007/s11926-010-0117-y.

4. Aletaha D, Smolen JS. Diagnosis and Management of Rheumatoid Arthritis: a review. JAMA. 2018;320(13):1360-72. https://doi.org/10.1001/jama.2018.131 03.

5. Baghdadi LR, Woodman RJ, Shanahan EM. The impact of traditional cardiovascular risk factors on cardiovascular outcomes in patients with rheumatoid arthritis: a systematic review and meta-analysis. PLoS One. 2015; 10(2):e0117952. https://doi.org/10.1371/journal.pone.0117952.

6. Radner H, Lesperance T, Accortt NA, Solomon DH. Incidence and prevalence of cardiovascular risk factors among patients with rheumatoid arthritis, psoriasis, or psoriatic arthritis. Arthritis Care Res. 2017;69(10):1510-8. https://doi.org/10.1002/acr.23171.

7. Myasoedova E, Gabriel SE, Matteson EL, Davis JM 3rd, Therneau TM, Crowson CS. Decreased cardiovascular mortality in patients with incident rheumatoid arthritis (RA) in recent years: dawn of a new era in cardiovascular disease in RA? J Rheumatol. 2017;44(6):732-9. https://doi. org/10.3899/jrheum.161154.

8. Blum A, Adawi M. Rheumatoid arthritis (RA) and cardiovascular disease. Autoimmun Rev. 2019;18(7):679-90. https://doi.org/10.1016/j.autrev.2019.05. 005.
9. England BR, Thiele GM, Anderson DR, Mikuls TR. Increased cardiovascular risk in rheumatoid arthritis: mechanisms and implications. BMJ. 2018;361:117.

10. Semb AG, Ikdahl E, Wibetoe G, Crowson C, Rollefstad S. Atherosclerotic cardiovascular disease prevention in rheumatoid arthritis. Nat Rev Rheumatol [Internet]. 2020;16(7):361-79 [acesso em 2020 out 18]. Disponível em: http://dx.doi.org/10.1038/s41584-020-0428-y.

11. da Mota LMH, Kakehasi AM, Gomides APM, Duarte ALBP, Cruz BA, Brenol CV, et al. 2017 recommendations of the Brazilian Society of Rheumatology for the pharmacological treatment of rheumatoid arthritis. Adv Rheumatol. 2018;58(1):1-17.

12. Singh JA, Saag KG, Bridges SL Jr, Akl EA, Bannuru RR, Sullivan MC, et al. 2015 American College of Rheumatology guideline for the treatment of rheumatoid arthritis. Arthritis Care Res. 2016;68(1):1-25. https://doi.org/10.1002/acr.22783.

13. Agca R, Heslinga SC, Rollefstad S, Heslinga M, Mclnnes IB, Peters MJL, et al. EULAR recommendations for cardiovascular disease risk management in patients with rheumatoid arthritis and other forms of inflammatory joint disorders: 2015/2016 update. Ann Rheum Dis. 2016;76(1):17-28. https://doi. org/10.1136/annrheumdis-2016-209775.

14. Gualtierotti R, Ughi N, Marfia G, Ingegnoli F. Practical management of cardiovascular comorbidities in rheumatoid arthritis. Rheumatol Ther. 2017; 4(2):293-308. https://doi.org/10.1007/s40744-017-0068-0.

15. Pereira IA, Mota LM, Cruz BA, Brenol CV, Fronza LS, Bertolo MB, et al. 2012 Brazilian Society of Rheumatology Consensus on the management of comorbidities in patients with rheumatoid arthritis. Rev Bras Reumatol. 2012; 52(4):474-95.

16. Nurmohamed MT, Heslinga M, Kitas GD. Cardiovascular comorbidity in rheumatic diseases. Nat Rev Rheumatol. 2015;11(12):693-704. https://doi. org/10.1038/nrrheum.2015.112.

17. Roubille C, Richer V, Starnino T, McCourt C, McFarlane A, Fleming P, et al. The effects of tumour necrosis factor inhibitors, methotrexate, non-steroidal anti-inflammatory drugs and corticosteroids on cardiovascular events in rheumatoid arthritis, psoriasis and psoriatic arthritis: a systematic review and meta-analysis. Ann Rheum Dis. 2015;74(3):480-9. https://doi.org/10.1136/a nnrheumdis-2014-206624.

18. Smolen JS, Landewé RBM, Biilsma JWJ, Burmester GR, Dougados M, Kerschbaumer A, et al. EULAR recommendations for the management of rheumatoid arthritis with synthetic and biological disease-modifying antirheumatic drugs: 2019 update. Ann Rheum Dis. 2020;79(6):S685-99.

19. da Rocha C-PG, Vargas-Santos AB, de Albuquerque CP, Bértolo MB, Júnior PL, Giorgi RDN, et al. The REAL study: a nationwide prospective study of rheumatoid arthritis in Brazil. Adv Rheumatol. 2018;58(1):9.

20. Hutchinson D. Classification criteria: the 1987 American rheumatism association revised criteria for the classification of rheumatoid arthritis. CPD Rheumatol. 1999; 1(1):13-4.

21. Aletaha D, Neogi T, Silman AJ, Funovits J, Felson DT, Bingham CO, et al. 2010 rheumatoid arthritis classification criteria: an American College of Rheumatology/European league against rheumatism collaborative initiative. Arthritis Rheum. 2010;62(9):2569-81. https://doi.org/10.1002/art.27584.

22. Ministério da Saúde. Secretaria de Vigilância em Saúde. Departamento de Vigilância de Doenças e Agravos não Transmissíveis e Promoção da Saúde. Vigitel Brasil 2017: Vigilância de fatores de risco e proteção para doenças crônicas por inquérito telefônico: estimativas sobre frequência e distribuição sociodemográfica de fatores de risco e de proteção para doenças crônicas nas capitais dos 26 estados brasileiros e no Distrito Federal em 2017 [recurso eletrônico]. Brasília: Ministério da Saúde, 2017. [acesso em 2020 fev 25]. Disponível em: https://bvsms.saude.gov.br/bvs/publicacoes/vigitel_bra sil_2017_vigilancia_fatores_riscos.pdf.

23. Acosta-Mérida Á, Naranjo A, Rodríguez-Lozano C. Prognostic Factors for Sustained Remission in a "Real Life" Cohort of Rheumatoid Arthritis Patients. Reumatol Clin [Internet]. 2020;16(5Pt2):405-9 [acesso em 2020 set 07]. Disponível em: https://doi.org/10.1016/j.reuma.2018.10.002

24. Wilson JC, Sarsour K, Gale S, Pethö-Schramm A, Jick SS, Meier CR. Incidence and risk of glucocorticoid-associated adverse effects in patients with rheumatoid arthritis. Arthritis Care Res. 2019;71(4):498-511. https://doi.org/1 $0.1002 /$ acr. 23611

25. Lee JL, Sinnathurai P, Buchbinder R, Hill C, Lassere M, March L. Biologics and cardiovascular events in inflammatory arthritis: a prospective national cohort study. Arthritis Res Ther. 2018;20(1):1-9.

26. Balsa A, Lojo-Oliveira L, Alperi-López M, García-Manrique M, OrdóñezCañizares C, Pérez L, et al. Prevalence of comorbidities in rheumatoid 
arthritis and evaluation of their monitoring in clinical practice: the spanish cohort of the COMORA study. Reumatol Clin. 2019;15(2):102-8. https://doi. org/10.1016/j.reuma.2017.06.002.

27. Crowson CS, Rollefstad S, Ikdahl E, Kitas GD, Van Riel PLCM, Gabriel SE, et al. Impact of risk factors associated with cardiovascular outcomes in patients with rheumatoid arthritis. Ann Rheum Dis. 2018;77(1):48-54. https://doi. org/10.1136/annrheumdis-2017-211735.

28. Myasoedova E, Chandran A, Ilhan B, Major BT, Michet CJ, Matteson EL, et al. The role of rheumatoid arthritis (RA) flare and cumulative burden of RA severity in the risk of cardiovascular disease. Ann Rheum Dis. 2016;75(3): 560-5. https://doi.org/10.1136/annrheumdis-2014-206411.

29. Humphreys JH, Warner A, Chipping J, Marshall T, Lunt M, Symmons DP, et al. Mortality trends in patients with early rheumatoid arthritis over 20 years: results from the Norfolk arthritis register. Arthritis Care Res. 2014;66(9): 1296-301. https://doi.org/10.1002/acr.22296.

30. Singh S, Fumery M, Singh AG, Singh N, Prokop L, Dulai PS, et al. Comparative risk of cardiovascular events with biologic and synthetic disease-modifying anti-rheumatic drugs in patients with rheumatoid arthritis: a systematic review and meta-analysis. Arthritis Care Res. 2020;72: 561-76.

31. Burggraaf B, Van Breukelen-Van Der Stoep DF, De Vries MA, Klop B, Liem AH, Van De Geijn GJM, et al. Effect of a treat-to-target intervention of cardiovascular risk factors on subclinical and clinical atherosclerosis in rheumatoid arthritis: a randomised clinical trial. Ann Rheum Dis. 2018:33541.

32. del Rincon I, Battafarano DF, Restrepo JF, et al. Glucocorticoid dose thresholds associated with all-cause and cardiovascular mortality in rheumatoid arthritis. Arthritis Rheum. 2014;66(2):264-72. https://doi.org/10.1 002/art.38210

33. Cardiel MH, Pons-Estel BA, Sacnun MP, Wojdyla D, Saurit V, Marcos JC, et al. Treatment of early rheumatoid arthritis in a multinational inception cohort of Latin American patients: the GLADAR experience. J Clin Rheumatol. 2012; 18(7):327-35. https://doi.org/10.1097/RHU.0b013e31826d6610.

34. Nissen SE, Yeomans ND, Solomon DH, Lüscher TF, Libby P, Husni ME, et al. PRECISION trial investigators. Cardiovascular safety of Celecoxib, naproxen, or ibuprofen for arthritis. N Engl J Med. 2016;375(26):2519-29. https://doi. org/10.1056/NEJMoa1611593.

35. Lindhardsen J, Gislason GH, Jacobsen S, Ahlehoff O, Olsen AMS, Ole Rintek Madsen, et al. Non-steroidal anti-inflammatory drugs and risk of cardiovascular disease in patients with rheumatoid arthritis: a nationwide cohort study. Ann Rheum Dis. 2014;73(8):1515-21. https://doi.org/10.1136/a nnrheumdis-2012-203137.

36. Johnson TM, Mikuls TR, England BR. Assessment of cardiovascular disease risk in rheumatoid arthritis. J Clin Outcomes Manag. 2019;26(1):41-7.

37. Giollo A, Bissell LA, Buch MH. Cardiovascular outcomes of patients with rheumatoid arthritis prescribed disease modifying anti-rheumatic drugs: a review. Expert Opin Drug Saf [Internet]. 2018;17(7):697-708 [acesso em 2020 set 07]. Disponível em: https://doi.org/10.1080/14740338.2018.1483331.

38. Radner H, Yoshida K, Hmamouchi I, Dougados M, Smolen JS, Solomon DH. Treatment patterns of multimorbid patients with rheumatoid arthritis: results from an international cross-sectional study. J Rheumatol. 2015;42(7): 1099-104. https://doi.org/10.3899/jrheum. 141534.

39. Low ASL, Symmons DPM, Lunt M, Mercer LK, Gale CP, Watson KD, et al. Relationship between exposure to tumour necrosis factor inhibitor therapy and incidence and severity of myocardial infarction in patients with rheumatoid arthritis. Ann Rheum Dis. 2017;76(4):654-60. https://doi.org/1 0.1136/annrheumdis-2016-209784.

40. Kang EH, Jin Y, Brill G, Lewey J, Patorno E, Desai RJ, et al. Comparative cardiovascular risk of Abatacept and tumor necrosis factor inhibitors in patients with rheumatoid arthritis with and without diabetes mellitus: a multidatabase cohort study. J Am Heart Assoc. 2018;7:e007393.

41. Jin Y, Kang EH, Brill G, Desai RJ, Kim SC. Cardiovascular (CV) risk after initiation of Abatacept versus TNF inhibitors in rheumatoid arthritis patients with and without baseline CV disease. J Rheumatol. 2018;45(9):1240-8. https://doi.org/10.3899/jrheum.170926 Epub 2018 May 15. PMID: 29764964.

42. Nurmohamed M, Choy E, Lula S, Kola B, DeMasi R, Accossato P. The impact of biologics and tofacitinib on cardiovascular risk factors and outcomes in patients with rheumatic disease: a systematic literature review. Drug Saf. 2018;41(5):473-88. https://doi.org/10.1007/s40264-017-0628-9.

\section{Publisher's Note}

Springer Nature remains neutral with regard to jurisdictional claims in published maps and institutional affiliations.

\section{Ready to submit your research? Choose BMC and benefit from:}

- fast, convenient online submission

- thorough peer review by experienced researchers in your field

- rapid publication on acceptance

- support for research data, including large and complex data types

- gold Open Access which fosters wider collaboration and increased citations

- maximum visibility for your research: over $100 \mathrm{M}$ website views per year

At BMC, research is always in progress.

Learn more biomedcentral.com/submissions 